\title{
What Are We Doing?
}

Douglas Rosenberg, University of Wisconsin-Madison

Simon Ellis, Centre for Dance Research (C-DaRE), Coventry University

Simon Ellis spoke with Doug Rosenberg via Skype on 20 December 2018.

SE: You and Claudia Kappenberg were the first editors of The International Journal of Screendance. Could you talk about some things you remember about getting IJSD started?

DR: I remember from the earliest days of these gatherings, all the way back to 2000 or so, what seemed to come up over and over again was the need for literacy. The word 'journal' came up a lot-something that put screendance in a similar territory to other art forms; a repository or something where people could write about the work, and think out loud. That came up really strongly at the first Opensource in 2006, ${ }^{1}$ but it wasn't until the second Opensource in $2007^{2}$ that it really got some traction. Then Claudia Kappenberg and Katrina McPherson put together an AHRC Network grant to create the Screendance Network. When that came through, it gave us the opportunity to meet over the course of two or three years in a number of different places, and we really started thinking in earnest about what a journal would look like and how we might go about creating it.

SE: You said these conversations about a place for writing and thinking about screendance were going on from about the early 2000s; was there any sense that this place was or should be a scholarly place?

DR: Certainly. That's a tricky word and the longer I've been involved in this sort of stuff the more I feel push back on that word because it does have a very narrow meaning in academia especially.

SE: If that's not the right word then what do you feel is more accurate or representative of the kind of writing that, at least initially, went on for the Journal?

DR: In my teaching experience and through going to conferences, the way that scholarly information and knowledge is conveyed always felt very middle-of-the-road ... very equivocal.

SE: Do you mean safe?

DR: Yes. What I've come to understand about scholarship is that most often it did the following when talking about a subject: "Well it could be this or it could be that. Either The International Journal of Screendance 10 (2019).

https://doi.org/10.18061/ijsd.v10i0.6823

(c) 2019 Rosenberg and Ellis. This article is published under a Creative Commons Attribution 4.0 International License (https://creativecommons.org/licenses/by/4.0/) 
are valuable but I'm going to tell you about both sides." And that was very frustrating to me, especially since what excited me, and what still excites me more than anything, are manifesto-driven movements. And out of one of the gatherings at Findhorn came a manifesto, and the entire first part of the 20th century all of the stuff that I would say screendance really flows from-Dada, futurism, surrealism - all those movements that were about interdisciplinary artists coming together for new utopian visions; those were all manifesto-driven, and so nobody would confuse that writing with scholarship the way we are talking about it right now. From my experience it isn't until the late 20th century when we start to get this thing that we talk about now as scholarship. Even at mid-century, Clement Greenberg's writing was more manifesto than scholarship.

SE: It was highly opinionated, that's for sure.

DR: Exactly, and that was always my model; and so that's a long response to what I think about when I think about the word scholarship, and we haven't even gotten into the word research which is another can of worms, right?

SE: Did you envisage initially that the journal was a place for Greenbergian-type writing: highly opinionated and more "This is the way things are"?

DR: Actually I think maybe more like October; that was more like what I was thinking about-interdisciplinary and contemporary writing. Or film journals like Millennium Film Journal, but Greenberg certainly was always in my head.

SE: I'm wondering about the people who write for IJSD, and I know it's hard to know the agendas of people when they submit to IJSD, but do you have a sense that those agendas might have changed since the beginning of the journal?

DR: I think that scholarship and research in an academic institution has this kind of magnetic pull, and once there is a space that opens up, then who has the drive to write for them? And it seems that people who are in Masters or PhD programs are compelled to write because of their programs, so ultimately those pages get filled up with the kind of scholarship that we were just talking about: somewhat equivocal and I don't mean that in a negative way ... a kind of professional scholarship. That idea does extend a little bit to publishing. For example, you may have an idea for searing utopian manifesto-like vision, but then in order to get that published it has to go through a number of hands and readers, and it's difficult to sustain that kind of intensity in an academic publication.

SE: There are certainly a number of filters that are applied in the process of publication. So what would you have done differently in terms of the development of IJSD?

DR: The only thing I wished could have endured was the paper copy. I'm still mourning the deaths of paper copies. I can't even imagine that IJSD has lasted for 10 issues. 
SE: How do you think the field of screendance has changed in the last ten or even 20 years?

DR: Well, I think that when films are made that are not mainstream, and not highly produced, and not heteronormative, and not fill-in-the-blank, the gravitational pull of screendance draws the field back into order. For every film that is 'outside the bubble' or moves the needle in a really aggressive way, there are a hundred films that pull that film back into orbit; that pull it back into maintaining the status quo. And I think that's true with the way that screendance is still presented; it's still presented in these one-off festivals. We still aren't seeing career retrospectives, or multiple works grouped together by single artist or by genre. Except in certain places, I mean Light Moves ${ }^{3}$ is doing an extraordinary job. I think the field-no matter how much we want it to change-somehow snaps back to its original forms.

SE: Are you saying that the field hasn't really changed in the last 10 years? That the kinds of films, the particular production values of films, but also the way in which they're presented, hasn't really changed?

DR: I think there are a number of artists in screendance who have made a lot of films, but there isn't a way that those films are grouped or put together. The festival model still persists, and we are still seeing a lot of first or second films in festivals. I think this is about getting older but I still see a misunderstanding —or lack of understanding - of the history of the medium. There are still some gaps in people's understanding of where things came from and how they got where they are. The flip side of that is that there have been a number of screendance publications in the last 10 years or so since the journal started; there's five or six books now that really focus on screendance; there's literature in the field. There are a lot of positive things about where the field is right now.

SE: I sense your frustration with the stasis in the field, about the kinds of films that are made, and how they are presented. What would your alternatives be in how films are presented?

DR: Well, MOMA in New York recently presented an extraordinary example; they held an exhibition (or perhaps retrospective) called "The Work is Never Done" about the Judson Church Group. It was fantastic. There were a lot of still images, there were films projected throughout the space that you could stand and watch in the company of all this other ephemera. There were reconstructions of work from that time period. So screendance or film dance was integrated into this museum exhibition in a lovely way. A lot of these films I'd only seen stills of, but the films themselves were extraordinary, and so contemporary looking.

SE: Are you suggesting that the presentation of screendance-even though it wouldn't have been called that then-in the context of something else, the placement of those 
films in something bigger is an ideal situation? Is that what you mean, or is it the sense of the retrospective itself?

DR: A little of both, but the context piece is really big. I've always proposed that screendance is an interdisciplinary art form, but ultimately when we're sitting in a theater at a screendance festival what we're seeing is a film-a monodisciplinary work. But screendance in the context of a more multidisciplinary space is really exciting. There's a lot of resonance when you see work like that. To a certain extent Light Moves has done this. They've shown screen work or installation work in the context of the festival, so there are a lot of things bouncing off each other, and the central theme is the body or movement, but site to site to site. It starts to have a different kind of resonance.

SE: It seems like what is driving your interest is interdisciplinary practices; that there are many ways to experience the world or how are senses are provoked or nourished.

DR: I've been inspired by the people involved in the genesis of the journal. For me part of making work or even not making work is about who I'm around. And so those gatherings-like in Findhorn in 2006 and 2007-were incredibly important. The journal came out of the friction and the tensions that happened when that group came together by accident. In the same way I think that manifestos are born; the way that movements come together.

SE: What else seems critical for you at this point in time?

DR: As we age, we have two choices. One is that we can pretend we are not ageing and that we can do everything we used to do. The other is to be with those changes, and the difference in your body, and the differences in everything about your life. Every age has a different sort of reality. I don't see very many bodies on screen that represent the age that people are at. We seem to be working with a very narrow bandwidth of virtuosity. What moves me very much is that there is gorgeousness about older bodies moving in space, or not moving but just being in space. I think that's a real hole in the field.

SE: Do you think that is a virus that has been passed on by dance's obsession with young bodies, of bodies aged say 16-30?

DR: I teach this art history course, and there's this spectrum of behaviour around actual bodies, that goes from the early 20th century-a modernist fetishization of exotic bodies (usually women, usually of color, usually from some other place that isn't Europe or America)-to a lot of work in which we see older ageing bodies, that also fetishizes those bodies. I think it's hard to work with ageing bodies, or lived bodies, without turning them into some kind of other, or without fetishizing those bodies. Mass media does that all the time.

SE: You mean mass media does that fetishization for us? 
DR: I think it does it really well.

SE: I'm paraphrasing you, but what I hear you saying is, "Who is that we are seeing in these films? What kinds of bodies? What kinds of people?"

DR: And what are they doing?

\section{Biographies}

Douglas Rosenberg is an interdisciplinary artist and theorist working with performance and media whose screendance projects have beed exhibited internationally for over 25 years. He is the author of Screendance: Inscribing the Ephemeral Image, and the editor of The Oxford Handbook of Screendance Studies, which was recently awarded the 2018 Oscar G. Brockett Book Prize for Dance Research, from the Dance Studies Association. He was, along with Claudia Kappenberg, a founding editor of the International Screendance Journal, and is currently a professor and Chair of the Department Art at University of Wisconsin-Madison.

\section{Email: rosend@education.wisc.edu}

Simon Ellis is a choreographer, dancer and film-maker interested in practices and ideas to do with (not necessarily at the same time) power, responsibility, memory, dialogue and screens. He is an Associate Professor at the Centre for Dance Research (C-DaRE) at Coventry University, and co-edits IJSD with Harmony Bench.

Email: simon.ellis@coventry.ac.uk

Website: www.skellis.info

\section{Notes}

${ }^{1}$ Opensource \{Videodance\}: Symposium 15th - 19th June 2006 Findhorn, Scotland

${ }^{2}$ Opensource \{Videodance\}: Symposium 21st - 24th November 2007 Findhorn, Scotland

${ }^{3}$ www.lightmoves.ie 